\title{
Patriarchy, Marriage and the Rights of Widows in Nigeria
}

\author{
Austin Obinna Ezejiofor \\ DOI: http://dx.doi.org/10.4314/ujah.v12i1.9
}

\begin{abstract}
Many women in several Nigerian communities dread the experience of widowhood. This is not just because of the pain arising from the loss of one's husband, but more so, as a result of the numerous dehumanising rituals and practices associated with widowhood. The fact that these practices are interpreted as being founded on the prevailing traditions of the people poses a bigger problem. But then, the question is: "what aspects of the tradition foster the violation of widows" rights and in what ways are these violations manifested? Employing the methods of analysis and description, this paper identifies patriarchy and marriage as the conceptual framework on which a proper of understanding widows' experiences in Nigeria is based. It argues that the institution of patriarchy and marriage, as aspects of the Nigerian traditional society, indeed, suffice as satisfactory explanations for the practice of widowhood in Nigeria. They foster the violation of widows' rights. Finally, as an integral part of its findings, the paper argues that the following constitute the manifestations of the violation of widows' rights: dethronement, defacement, forced levirate marriage; disinheritance and denial of the right of dignity and equality.
\end{abstract}

\section{Introduction}

With the wave of feminism in Nigeria, one would think that all acts of injustice and humiliation against women would become a thing of the remote past. Since a decade or so ago, the phrase 'women empowerment' has become a common 
terminology among social science researchers and indeed, among Nigerian youths, mainly the females. The government, in a bid to demonstrate its support for this movement, has been quick to create Centres for Women Development both at state and federal levels. This change in the Nigerian polity, though positive, does not in actuality bring an end to the numerous woes encountered by women on regular basis. Severally, women are viewed as secondclass citizens and as such, they remain at the receiving end of the ignominious acts of discrimination, contempt, neglect, victimization (including sexual) and other forms of human rights violations. The thought that some of these unwholesome acts are founded on the traditions, culture and structures of the Nigerian society is disturbing. One good example in this direction is the case of widowhood in Nigeria. This forms the subject of our study.

Widowhood in Nigeria is not only perceived as a state of being, but more importantly as an institution. Ordinarily, one would say that widowhood "is the state or condition of being a widow, or, rarely, of being a widower" (Webster's Dictionary 1438), but when we take into account the very many rituals and practices together with the regulations and impositions that go along with it, we will find out that widowhood is, more or less, an institution. This institution is interpreted and understood in the context of the culture and traditions of the people which regulate its operations. To this end, every woman whose husband dies is expected to adhere strictly to the unwritten ordinances and rituals of widowhood which are argued to be imposed by the culture and tradition. To be sure, widowhood is an experience most women in Nigeria and perhaps in Africa dread to have. Such women are subjected to several inhuman treatments like rejection, abuse, denial, oppression, subjugation and defilement, and to them it is best described as a nightmare. 
It is, however, problematic why practices such as these directed against widows are interpreted and justified as emanating from the peoples' tradition and these women are meant to believe that they cannot challenge the dictates of the tradition. But then, the question is "what aspects of the tradition foster the violation of widows' rights and in what ways are these violations manifested?"

Theoretically, this paper bases its claims on literature derived from secondary sources and employs basically the methods of analysis and description. It is laid out in the following outline: after the introduction, the conceptual framework, with particular attention to patriarchy and marriage, is handled. This is followed by discussing the realities of widowhood in Nigeria and the rights of widows. The next two sections introduce us to the manifestations of the violation of widows' rights and the effects of such violation respectively. This is finally followed by the conclusion.

\section{Conceptual Framework}

While acknowledging the apparent neglect of researches on the plight of widows which leads to scarcity of relevant literature on the subject (Von Strueusee 1), we would want, at this juncture, to explore the theoretical explanations for the practice of widowhood in Nigeria. Our principal task here is to consider the rationale for the practice. With reference to a WHO report in Nigeria (Division for the Advancement of Women 9),

The low status, poverty and violence experienced by widows stem from discrimination in inheritance, custom, the patriarchal nature of the society, and the domination of oppressive traditional practices 
and customary codes, which take precedence over constitutional guarantees of equality, modern laws and international women's human rights standards.

A number of issues are raised here which are of importance to us, but let us begin by looking at the problem of patriarchy upon which several other aspects of gender discrimination against women are hinged.

\section{Patriarchy}

In manners best described as demeaning, several persons have conceived and described the world as 'men's world'. Women can only play the second fiddle to men. They stand to be subjugated and dominated by men. Their participation in political, economic and religious affairs, and of course other power-concentrated spheres, is highly restricted. This is the case not only in Nigeria or other non-Western countries, but also in industrialized countries. The restrictions placed on women getting certain jobs and even earning less than their male counterparts in Western countries simply remind us of how endemic discrimination against women is. The concept that best qualifies this realist perception of the society is patriarchy. We adopt the definition by Stopler which sees patriarchy "as the manifestation and institutionalization of male dominance over women in the society." (365)

This definition generates a lot of curious questions. Is it not enough to define patriarchy as male dominance over women in the society? Why is it necessary to have this dominance institutionalized? What are the possible means of achieving the institutionalization? How is this dominance manifested? May we first of all observe that no meaningful understanding of gender relations can be achieved in the absence of proper power relations, for a discourse on gender 
relations is, invariably, a discourse on power relations. Power is not just a phenomenon associated only with those who have the presumed political will to command obedience from others or which only explains the relationship between the state, together with its instruments and its citizens or subjects. In addition to but more important than this, power is a social phenomenon and as such is everywhere. For Foucault, according to Stopler, power, given its social nature, is defined "by a more-or-less organised, hierarchical, co-ordinated clusters of relations", whose acceptance is predicated on the premise that "it induces pleasure, forms knowledge and produces discourse." (366)

This applies perfectly in the context of our discussion, for history tells us that the persistent effort by men, in the name of patriarchy, to dominate women is only an indication of power struggle. For many years, men have dominated the arenas of knowledge formation and discourse production. They occupied all known positions in politics, science, education, and so on. But with the flourishing of feminism, individualism, liberalism and other forms of critical theories in the twentieth century, a reversal to the male-dominated discourse was introduced. Though the theory of male dominance is, today, a resisted discourse, efforts are still being made to maintain the status quo. It therefore follows that through the institutionalization of male dominance over women, it becomes easier to attain, wield and exercise power. After all, he who plays the flute dictates the steps.

Furthermore, Stopler, making reference to the anthropologist Sherry Ortner, observes that women are considered inferior to men in every known culture. To substantiate this claim, she points out three types of data as follows 
(1) element of cultural ideology and informants' statements that explicitly devalue women, according them, their roles, their tasks, their products, and their social milieu less prestige than are accorded men and the male correlates; (2) symbolic devices, such as the attribution of defilement, which may be interpreted as implicitly making a statement of inferior valuation; and (3) social-structural arrangements that exclude women from participation in or contact with some realm in which the highest powers of the society are felt to reside. (365)

These data indicate clearly the institutionalization of male dominance over women. In the light of the above, it suffices to say that the practice of widowhood in Nigeria is at least one clear way the institutionalization of male dominance over women is manifested. The widows merely exist under circumstances where they cannot accentuate their personhood or humanity. They are dehumanized and robbed of their personhood, for they do not define themselves, rather are defined by their male counterparts, especially during the early stages of widowhood. In order to maintain this hegemony of patriarchy in the Nigerian society, a rather prejudiced reference is constantly made to the gender-insensitive custom or tradition.

\section{Marriage}

There is a strong relationship between circumstances of a woman's marriage and her experiences in the case of the death of her husband. In Nigeria, there are basically three types of marriage namely: statutory marriage, customary marriage and Islamic marriage. Arguably, these roughly coincide with Christian culture, traditional African culture 
and Arabic and Islamic culture. (Sagay, 168) However, in most cases, there is fusion of culture and religion (Islam, Christianity and African Traditional Religion) in the Nigerian society and this makes it difficult to interpret or assess clearly any given situation or occurrence. Determining whether a particular practice is influenced by religion or traditional culture is very difficult.

Widowhood, for instance, is a case at hand. Statutory (civil) marriage is understood as monogamous marriage, which is mostly viewed from the perspective of Christian religion. When contracted in the church, it is a common practice in Nigeria today that the couple should first get married or registered officially in the government's Registry office before coming to the church to institute the marriage. We would like to mention at this point that this is a progressive step to protect the rights of women in the case of divorce or death of their husbands. Under Islamic marriage, which is contracted according to the provisions of Islamic religion, the rights of widows are considerably protected. According to the Quran 2:240 as cited in http://www.islamicity.com/mosque/w_islam/widows.htm,

Those of you who die and leave widows should bequeath for their widows a year's maintenance and residence. But if they (the widows) leave the residence, there is no blame on you for what they justly do with themselves.

In spite of the above provision, widows in the northern part of Nigeria (Islam dominated) are subjected to similar hideous conditions their counterparts in other parts of Nigeria suffer under. It simply brings to the limelight the already mentioned intertwining of religion and culture. The customary marriage is such contracted according to culture 
and traditions of the land. This is why it is also called traditional marriage. This usually involves the traditional payment of dowry. Due to the importance associated with this form of marriage, most people who contract statutory and Islamic marriage always fulfil the customary marriage obligations. In fact, in most parts of Nigeria, a marriage relationship is not valid until this part is fulfilled. Customary marriage, though acceptable in its own merits, occasions the many troubles widows go through. Vanessa von Strueusee citing Ncube succinctly writes:

Under customary law, all meaningful property is owned and controlled by the husband. Women are often, if not always, reduced to the status of property-less dependents who have to submit to the will of their husbands in order to survive. The customary law on matrimonial property perceives a married woman as an unpaid servant of her husband. She works for him, looks after his family, acquires and preserves property for him. (8)

It is obvious that the treatments against widows are harsher under the provisions of the customary marriage law. As indicated earlier, this is already a resisted discourse in Nigeria today. We shall consider later what efforts are being made to resist this knowledge.

\section{The Realities of Widowhood in Nigeria}

It is obvious that the term 'widowhood' may refer to both widows and widowers, but in the context of this paper, it is used strictly for widows. This is, of course, the most common usage. Despite the fact that there are over 250 different ethnic groups in Nigeria, the conception of widowhood and the 
rituals widows go through are the same. These experiences define their status as destitute and vulnerable. According to the reports of the World Health Organisation (WHO) in Nigeria, family law permits certain widowhood practices which discriminate against women, especially women married according to customary rather than statutory law. At the occasion of the death of her husband, the woman is seen as unclean and impure. She is subsequently subjected to customs that even undermine her health. The situation is worse if she has no male child, in the case of which she may be ejected from her husband's house whereas his house and land will be inherited by his brother(s). In most cases, the husband's kin do not provide the widow with any economic support, particularly if she refuses to be an additional wife to one of her husband's brothers. (Division for the Advancement of Women 9) Thus, widows are exposed to untold hardships including homelessness, insecurity, hunger, poverty, illness and rejection. In many cases, they will have to withdraw their children (non adults) from school because they do not have enough means of livelihood let alone paying the fees of the children in schools. Sometimes, to make ends meet, some widows take to prostitution, which invariably increases their chances of being infected with different deadly diseases, including HIV/AIDS.

However, the fact that men who lose their wives do not have similar experiences makes the injustices widows face more pronounced. It calls to attention, once again, the question of discrimination against women in virtually every sphere of social life in Nigeria. In the widowers' case, they go through some mourning rites as they please and no sanctions are imposed on them. Ewelukwa captures it succinctly: 
If a wife dies, the man is confined in the house for a month but the men break the rules. It cannot be an abomination if he breaks the rule but people can talk. There are no sanctions. Maybe sanction by shunning. It becomes an abomination if he impregnates another woman during that mourning period. (439)

While men may mourn their wives for one month (which they hardly do) by not showing up at certain public functions like festivities, parties and celebrations, the widows are expected to mourn their husbands for six months. Sometimes, it could be three months or more than six months. During this period, she is allowed the minimum of clothing just enough to cover her nakedness; she is made to sleep on the bare floor and to eat with broken plates. In rural areas and sometimes in urban areas, widows, not widowers are forced to wear a particular black or white dress which immediately subjects them to stigmatization in the society. In fact, there is no end to the list of gendered discriminating acts against widows. Umorem, (1995) corroborates this when he observes that "a widow is subjected to these indignities (degrading rituals) and a widower is not. He remarries, if he so wishes, at will"

\section{Rights of Widows (Women)}

The Universal Declaration of Human Rights (UDHR), adopted by the General Assembly of the United Nations on 10th December, 1948, specifically emphasizes the freedom and equality of all in dignity and rights, the absence of torture and inhuman treatment, free and full consent to marriage, and right to ownership of property. (http://www.un.org/en/documents/udhr) In addition to this, the Convention on the Elimination of all Forms of Discrimination against Women (CEDAW) adopted by the 
UN General Assembly on 18th December, 1979 contends for the condemnation of discrimination against women in all its forms, elimination of prejudices and customary and other practices which are based on the idea of the inferiority or superiority of either of the sexes and right to family benefits, choice of spouse and marriage. In this convention, which is the very first one to address squarely the negativities of some customary practices, discrimination against women is referred to as

... any distinction, exclusion or restriction made on the basis of sex which has the effect or purpose of impairing or nullifying the recognition, enjoyment or exercise by women, irrespective of their marital status, on a basis of equality of men and women, of human rights and fundamental freedoms in the political, economic, social, cultural, civil or any other field.

As would be shown later, these provisions corroborate the subsequent effort to protect women from gender-based violence as put forward by the Declaration on the Elimination of Violence against Women adopted by the UN General Assembly on 20th December, 1993. (http://www.un.org/documents/ga/res/48/a48r104.htm)

Gender-based violence is understood as violence resulting in physical, sexual or psychological harm or suffering to women, including threats of such acts.

Similarly, the Protocol to the African Charter on Human and Peoples' Rights: On the Rights of Women in Africa, which entered into force on 25th November, 2005 pays careful attention to the plights of widows. This is not a huge surprise as it seems widows suffer the most in Africa 
more than in any other continent. Article 20 of the Protocol states as follows: (i) that widows should not be subjected to inhuman, humiliating and degrading treatment; (ii) that a widow shall automatically become guardian and custodian of her children unless it is contrary to the interest and welfare of the children and (iii) that a widow has the right to remarry and to whomsoever she chooses. On the right to inheritance, the protocol in

Article 21 (http://www.achpr.org/english/_info/women_en.html) maintains that a widow shall have the right to an equitable share in inheritance of the property of her husband: to continue to live in the matrimonial house, if remarried, she has the right of ownership of property belonging to her in her first marriage.

\section{Manifestations of the Violation of Widows' Rights}

A cursory reflection on these human rights documents reveals instantly some points of human rights violations manifested by the institution of widowhood and its inherent practices. Let us just consider a few.

\section{Defacement and Dethronement}

The ordeals of a widow begin with what this paper addresses as defacement and dethronement. In the traditional Nigerian society (just as in other African context), the man is seen as the crown (head) of his wife. A woman is never assessed in isolation from her husband. Whatever she is or has attained is attributed to her husband: her beauty, achievements, wealth, property and so on. In fact, she belongs to him wholly and entirely. Nevertheless, in the event of the death of her husband, one of the first things done to this woman is to debase her, to reduce her to nothingness. These acts of defacement and dethronement take various forms depending on locations. The commonest observations, irrespective of 
location (rural or urban area), include shaving completely the widow's hair, stigmatizing her with a particular mourning dress, forcing her to sleep on bare floor, possibly staying for days without a bath (being exposed to contaminations and disease infections), and forcing her to wail, sometimes very noisily and injuring herself in the process. A civil servant who was subjected to most of these treatments after the death of her husband revealed she gave in as a result of fear of being accused of killing her husband. This stems from the notion in some traditions that death is not a natural occurrence. Mostly in rural areas, widows are subjected to what is called ritual cleansing. This, according to von Strueusse, takes different "forms including the widow's bathing or sleeping with the husband's body and the widow's having sexual intercourse with her brothers-in-law" (20)

Forced Levirate Marriage

Levirate marriage, which also means widow inheritance, simply refers to a situation where a male member of a family inherits a widow after the death of her husband. According to a report by the Amnesty International,

... some customary law systems ... prescribe that a widow (be) 'inherited' by a male relative of the former husband. The widow is seen as the property of the former husband's family. Families that migrate to Lagos continue to apply such customary rules to their relationships, even after they have moved away from their traditional areas of origin. (8)

Apart from the initial attempt to humble a widow by the relatives of the deceased man, her woes and troubles often 
begin if she tries by any means to resist such advances which, sometimes, culminate in sexual harassment. Nowadays, sometimes, if the man had no children or only one kid before his death, his relatives sometimes plead with the widow to consider marrying any man of her choice from amongst them. This is mostly the case if the relatives come to terms with the fact that the widow is enlightened and empowered through education. (Merry, 11)

Disinheritance

Contrary to Article 21 of the Protocol on the Rights of Women in Africa, many widows are denied of their right to inheritance. Since they are perceived as inheritable property themselves according to the customary laws, it goes without saying that have no entitlement to property ownership at the occasion of the death of their husbands. This is, especially, the case if the widow has no grown up male child. That women and girl children, traditionally, have no property inheritance right in many parts of Nigeria is not news. Worthy of mention are the types of property widows are denied; they include land, houses (including matrimonial homes), cash and other assets. In rural areas where most women depend on sale of agricultural proceeds for a living, such act of disinheritance obviously rob them and their young children livelihood. This is even a greater form of human rights violation.

Korieh (1996), who carried out a field research on the subject in the south-eastern part of Nigeria, recounts the experiences of some widows. One was forced to hand over the pass book (bank savings book) of her husband by his relatives after they had ordered her home from Lagos to explain the cause of his death. It was even worse for the other since their entire property was confiscated. Her husband's relatives sent a lorry from home to pack all his electronics 
and merchandise in his supermarket. Such inglorious actions could, apart from hinging on the already discussed theory of patriarchy, be associated with the harsh economic reality, heightened by unemployment which these men face. If they had good jobs or were economically balanced, hardly would they pay attention to acquiring the property of their late brother.

\section{Denial of Right to Dignity and Equality}

The practice of widowhood, on a very large scale, results to discrimination against women and the denial of their right to human dignity and equality. There is no act that dehumanizes a person as treating him or her like a piece of property, which could be used or discarded. In a nutshell, this is a description of the widow's everyday experience, usually at the early stages of widowhood. Sometimes, a widow is accused of witchcraft; she is accused of having killed her husband. Such act of accusation is usually a preconceived strategy used by the relatives of the dead man to beat the widow off her guards. Severally, widows are forbidden from working, hence denying them the right to earn a decent living.

\section{Effects of the Violation of Widows' Rights}

One of the greatest effects of the practice of widowhood on widows is psychological. The fear and stigmatization associated with being a widow create some sort of emptiness in the widows, which sometimes, leaves them perpetually wounded. The ridicule, accusations, deprivation, sexual harassment and defacement continually have psychological effects on them. Such psychological injury or damage constitutes exactly what the Declaration on the Elimination of Violence against Women tries to avoid. 
Another important effect of the practice is that it exposes widows to all form of diseases and health problems. Being forced to sleep on the bare ground, to stay for many days without having a bath, irrespective of whether they are having their menstrual cycle at that moment simply make them very vulnerable to infections. Besides, the practice of widow inheritance (levirate marriage), with all the gimmicks that go with it, has been pointed out as one of the reasons for the spread of HIV/AIDS in Nigeria and Africa as a whole. Succinctly put, von Strueusse argues that "widow inheritance, the practice of forcing a widow to marry a male relative of her deceased husband...contributes to the cycle of women's disempowerment and the spread of HIV." (23)

Furthermore, the state of destitution, poverty, rejection and homelessness of widows is nothing to write home about. Little wonder they are perceived as "the poorest of the poor, the most oppressed, violated and invisible and their voices are the most unheard." (Von Strueusse 1) Sometimes, their situation passes unnoticed, even by the government. Some resort to all kinds of jobs, including prostitution, to make a living and the situation becomes tougher; they withdraw their children from school. This invariably contributes to the increase in illiteracy level among children, especially in rural areas, which would later affect the workforce of the country as a whole. The experience of widows is not unconnected with child marriage. Many of them, due to the intensity of their suffering, give out their young female children for marriage, thereby exposing them to the risk of early widowhood. It is simply a vicious cycle!

\section{Conclusion}

This paper has attempted to focus on the plight of widows in Nigeria, with particular attention to the rationale for the treatments against them, the international human rights 
documents or provisions for their protection, how their rights are violated and the effects of these violations on them,. Among other reasons, it is herein argued that the notions of patriarchy and marriage in the Nigerian society are contending reasons/factors for the sustenance of the marginalized practice of widowhood in Nigeria. Patriarchy, which is perceived as the institutionalization and manifestation of male dominance over women in the society, accounts for why women generally and widows in particular are constantly subjugated and discriminated against. Besides, the provisions of the customary marriage law in Nigeria contribute substantially to the violation of widows' rights. According to the customary law, a woman is seen as a property of her husband. She is inherited and as such is completely excluded from all inheritance rights, even at the occasion of the death of her husband. It is, however, observed that though such traditional practices are still upheld in Nigeria, especially in the rural areas, the exploited practice of widowhood is already a resisted discourse. This resistance is attributed to the changing culture and value of the Nigerian society. This, notwithstanding, the following are projected as the manifestations of the violation of widows' rights: dethronement, defacement, forced levirate marriage; disinheritance and denial of the right of dignity and equality. 


\section{References}

Amnesty International, Nigeria. Unheard Vioces: Violence Against Women in the Family. 2005. March 07, 2011

<http://www.amnesty.org/library/pdf/AFR440042005ENGLI SH/\$File/AFR4400405.pdf>

Ewelukwa, Uchechukwu. "Post-Colonialism, Gender, Customary Injustice: Widows in African Societies." Human Rights Quarterly 24.2, (2002): 424-487.

Korieh, Chima. Widowhood among the Igbo of Eastern Nigeria. $1996 . \quad$ March 07, 2011 <http://www.ub.uib.no/elpub/1996/h/506001/korieh/ chima.html>

Merry, Sally Engle. Human Rights and Gender Violence: Translating International Law into Local Justice.

Chicago: University of Chicago Press, 2006.

Sagay, Itse. "Widow Inheritance versus Monogamous Marriage: The Oba's Dilemma" Journal of African Law 18.2, (2009): 168-172.

Stopler, Gila. "A Rank Usurpation of Power - The Role of Patriarchal Religion and Culture in the Subordination of Women" Duke Journal of Gender, Law and Policy 15, (2008): 365-398.

The New International Webster's Comprehensive Dictionary of the English Language: Encyclopaedic Edition, Florida: Typhoon International Corporation, 2004.

Umorem, U. E. Enculturation and Inculturation: The Gospel of Liberation and the Culture of African Womanhood. 1995. March 09, 2011 <http://www.sedos.org/english/umorem.htm>

UN Division for the Advancement of Women. Widowhood: Invisible Women, Secluded or Excluded, 2001. March 09, 2011 
<http://www.un.org/womenwatch/daw/public/wom_Dec\%20 01\%20single\%20pg.pdf>

Von Strueusee, Vanessa. Widows, AIDS, Health and Human Rights in Africa. 2007. March 05, 2011

$<$ http://liphea.org7featurepresentationpages/jameskeytransfor mationalstewardship/additional-readings-andwebsites7documents-and-resources $>$

http://www.achpr.org/english/_info/women_en.html (Last access: 08/03/2011).

http://www.islamicity.com/mosque/w_islam/widows.htm (Last access: 08/03/2011).

http://www.unesco.org/en/human-rights-education (Last access: 07/03/2011).

http://www.unhcr.org/refworld/topic,463af2212,469f2db72,4 5f1478811,0.html (Last access: 09/03/2011).

http://www.un.org/en/documents/udhr (Last access: 08/03/2011).

http://www.un.org/documents/ga/res/48/a48r104.htm (Last access: 08/03/2011).

http://www.un.org/womenwatch/daw/cedaw (Last access: 08/03/2011). 